\title{
Optimizing Needs Fresh Air for Healthy Microclimate
}

\author{
Zdenek Galda $^{1 *}$, Jiri Labudek ${ }^{1}$ \\ ${ }^{1}$ VSB - Technical University of Ostrava, Department of Indoor Environmental Engineering and Building Services - 229, Faculty of Civil \\ Engineering, 70833 Ostrava, Czech Republic
}

\begin{abstract}
The aim of the experiment was to verify the $\mathrm{CO}_{2}$ concentration in the indoor environments in different flows of fresh air per person, based on the legislative requirements of the Czech Republic and the European Union. The experiment was performed in a passive house at the Faculty of Civil Engineering, VSB - Technical University of Ostrava. Legislative requirements regarding minimum fresh air flow $\left(25 \mathrm{~m}^{3} / \mathrm{h}\right)$ according to the measurements do not comply with the recommended limits on $\mathrm{CO}_{2}$ concentration of the valid legislation. The paper analyzes the impact of variable fresh air flow on $\mathrm{CO}_{2}$ concentrations in the interior of building. The article describes the method of the experiment and evaluate the results of the real test.
\end{abstract}

\section{Introduction}

The mechanical airing should mainly ensure a supply of fresh, hygienic air and the removal of unnecessary humidity while keeping the concentration of $\mathrm{CO}_{2}$ low (below $1000 \mathrm{ppm}$ according to the Pettenkofer criteria, [3]), and removing other harmful substances in the interior. The development of the listed toxic substances is caused predominantly by general, everyday activities and by the flora present in the room. [2].

Our today's internal microclimate of a building changes in relation to the increasing air-tightness of modern, low-energy, passive and zero homes. The main purpose of increasing the air-tightness of buildings is mainly the economical and profitable usage of energy necessary to heat a house. The gross thermal loss consists of two parts; thermal loss due to construction penetration and thermal loss caused by airing. The latter is, in the case of economical homes, suppressed by the airtightness of the building's facade.

Fresh air is thus transferred to the interior in varying seasons. Most often, air is brought in mechanically, with the aid of an air-tight appliance, where it goes through a recuperator and is eventually mixed with circulating air and then warmed. Then it travels to individual rooms as needed [4].

\section{Description of Experiment}

Experimental measurements were performed from $19^{\text {th }}$ to $26^{\text {th }}$ August 2015 in the experimental passive house at the Faculty of Civil Engineering, VSB - Technical University of Ostrava in Ostrava city (about $250 \mathrm{~m}$ above sea level), in Europe. Atmospheric pressure during the measurement ranged from 98.27 to $98.98 \mathrm{kPa}$.

The experimental house is a modified standardized family house. It is a light wooden structure with a diffusion-open envelope cover. Energy performance of the building is $10 \mathrm{kWh} / \mathrm{m}^{2}$, heat loss is $2 \mathrm{~kW}$ and airtightness of the object is $\mathrm{n}_{50}=0.45 \mathrm{~h}^{-1}$. Measurements were performed in the upper chamber, the volume of the room being $50.2 \mathrm{~m}^{3}$. Ventilation of fresh air was controlled using Siemens Desigo software and subsequently checked using flow Testo gauges in the tested room's diffusers.
Air inlet and outlet were proportional. The test concerned only ventilation of the space with outside fresh air. Measurement was carried out with the participation of one person performing routine office work. The main observed values were internal $\mathrm{CO}_{2}$ concentration, internal relative humidity and internal temperature. Furthermore, the values of outside $\mathrm{CO}_{2}$ concentration and outside temperature were measured. Tested person (Zdenek Galda) was the figurant.

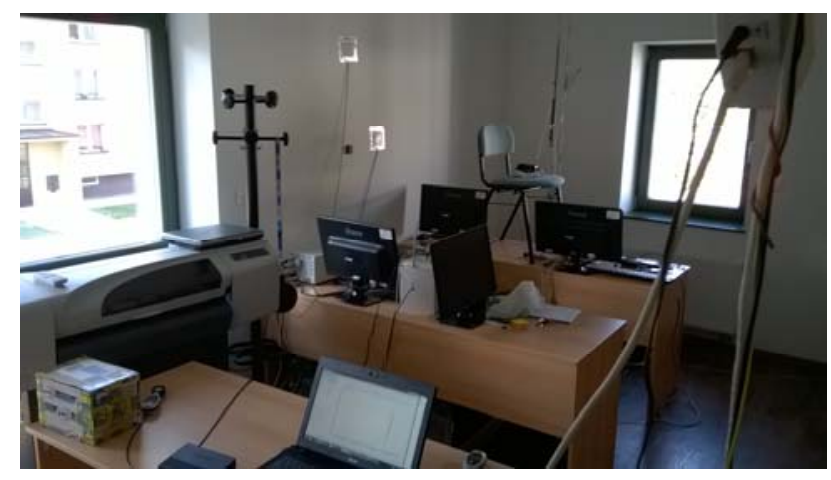

Figure 1. View of the tested room (capacity $50.2 \mathrm{~m}^{3}$ ). There are $\mathrm{CO}_{2}$ sensors hung in the corner.

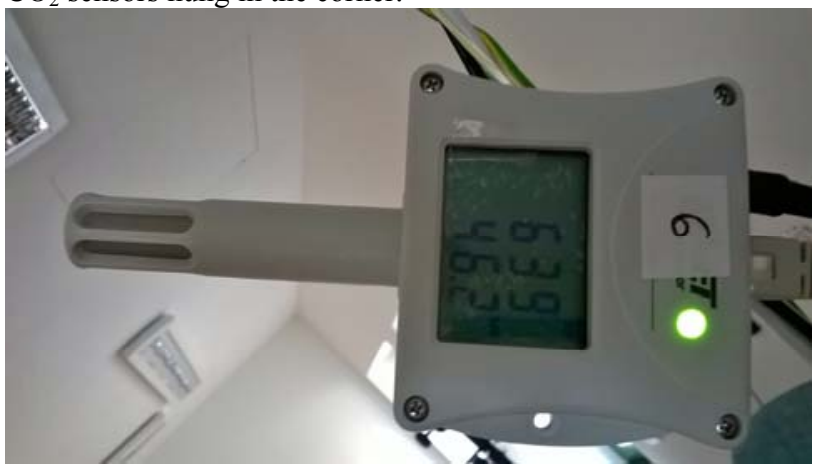

Figure 2. Comet $\mathrm{T} 6450 \mathrm{CO}_{2}$ sensor (No. 6) with output on Ethernet, measuring range $0.00-10000.00 \mathrm{ppm}$.

An adult man usually ventilates the lungs about 15 times per minute. The ventilation volume is about $500 \mathrm{ml}$, which corresponds to about 0.45 to $0.50 \mathrm{~m}^{3} / \mathrm{h}$. The recommended concentration of $\mathrm{CO}_{2}$ in a living area is max. 1000 ppm according to Max Joseph von Pettenkofer Criteria. The maximum current value valid for the Czech 
Republic is $1500 \mathrm{ppm}$ [5]. This value applies to residential rooms (previously it was $1000 \mathrm{ppm}$ ).

\subsection{Legislative criteria}

Czech technical standard CSN EN 15665:2011 gives the minimum dose of fresh outdoor air at $15 \mathrm{~m}^{3} / \mathrm{h}$ per person, while the recommended value is $25 \mathrm{~m}^{3} / \mathrm{h}$ per person [4]. For other room types the requirements are given according to the so-called "class of work". European technical standards recommend similar criteria and values.

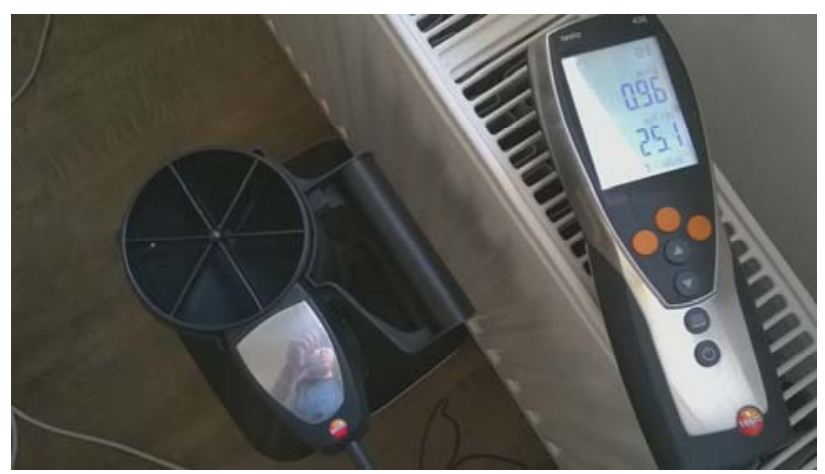

Figure 3. Checking flow volume at outlet (Testo 435-2, anemometer and Testovent 417).

\section{Measurement}

Before measurement of the low flow rating $\left(15 \mathrm{~m}^{3} / \mathrm{h}\right.$ and $25 \mathrm{~m}^{3} / \mathrm{h}$ ), the room was well ventilated via the windows to a value of $500-600 \mathrm{ppm}$ to increase the $\mathrm{CO}_{2}$ concentration. At higher flow ratings, it was not necessary to ventilate the room.

For each measurement, at the beginning and at the end, the $\mathrm{CO}_{2}$ concentrations in the outdoor air were observed. And each measurement took at least two hours. During all measurements the weather was sunny and summery with a slight breeze. Only when measuring the flow rate of $50 \mathrm{~m}^{3} / \mathrm{h}$ (rainy, grey line), did it start to extensively rain after 1 hour $16 \mathrm{~min}$, but $\mathrm{CO}_{2}$ values increased only slightly, the values are shown in Table 1.

\section{Measured results \\ 4.1 Result from central system Desigo}

The first outcomes are from the central computer system Siemens Desigo picks the all data (interior and exterior temperatures, $\mathrm{CO}_{2}$, indoor relative humidity, relative humidity in the constructions, lighting, temperatures in the walls, roof, temperatures in the soil under the house, tension in the footing bottom, energy consumption) from the whole experimental house. External $\mathrm{CO}_{2}$ values are in the first line of the table, $\mathrm{CO}_{2}$ values were separated to the table, see below.
Table 1. Concentration of $\mathrm{CO}_{2}$ in tested room with variable flow of fresh air.

\begin{tabular}{|r|c|c|c|c|c|c|}
\hline Outer CO2 [ppm] & $\mathbf{3 3 0 - 3 4 0}$ & $\mathbf{3 7 0}$ & $\mathbf{3 5 5 - 4 4 0}$ & $\mathbf{3 9 5}$ & $\mathbf{3 7 0 - 5 0 0}$ & $\mathbf{3 8 5 - 4 3 0}$ \\
\hline Fresh air [m3/h] & $\mathbf{1 5}$ & 25 & $\mathbf{5 0}$ & $\mathbf{5 0}$ & $\mathbf{4 0}$ & $\mathbf{6 0}$ \\
\hline $0: 00: 00$ & 582.4 & 652.4 & 596.0 & 636.0 & 802.0 & 783.8 \\
\hline $0: 10: 00$ & 603.4 & 694.2 & 616.6 & 677.2 & 823.0 & 763.2 \\
\hline $0: 20: 00$ & 707.2 & 715.2 & 637.4 & 677.2 & 823.0 & 763.2 \\
\hline $0: 30: 00$ & 791.0 & 735.8 & 679.2 & 719.2 & 823.0 & 763.2 \\
\hline $0: 40: 00$ & 853.2 & 776.8 & 701.0 & 739.4 & 844.0 & 804.4 \\
\hline $0: 50: 00$ & 916.0 & 839.0 & 701.0 & 739.4 & 864.6 & 804.4 \\
\hline $1: 00: 00$ & 978.8 & 881.0 & 701.0 & 739.4 & 885.0 & 804.4 \\
\hline $1: 10: 00$ & 1041.6 & 902.6 & 722.0 & 739.4 & 885.0 & 804.4 \\
\hline $1: 20: 00$ & 1062.4 & 943.8 & 742.2 & 760.2 & 885.0 & 825.0 \\
\hline $1: 30: 00$ & 1187.4 & 1005.8 & 742.2 & 760.2 & 885.0 & 804.0 \\
\hline $1: 40: 00$ & 1208.4 & 1005.8 & 763.0 & 781.0 & 926.8 & 802.1 \\
\hline $1: 50: 00$ & 1250.4 & 1026.6 & 784.0 & 781.0 & 968.8 & 804.0 \\
\hline $2: 00: 00$ & 1271.2 & 1047.6 & 784.0 & 781.0 & 978.2 & 804.0 \\
\hline
\end{tabular}

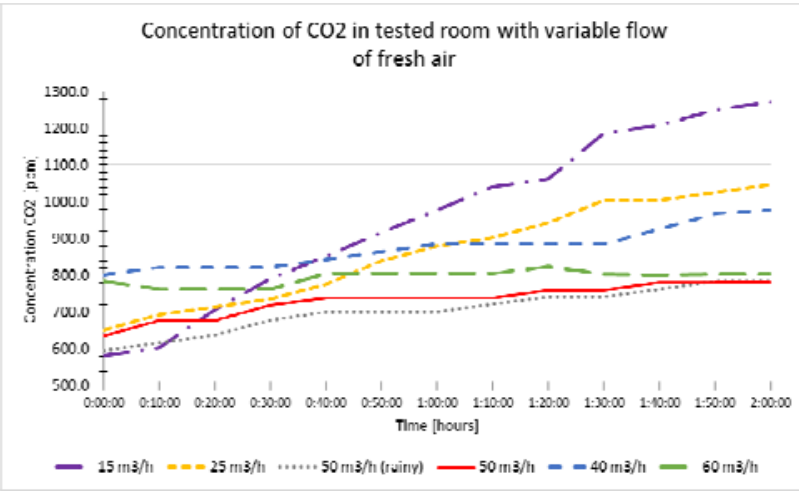

Figure 4. Concentration of $\mathrm{CO}_{2}$ in tested room with variable flow of fresh air.

Generally, it can be said that the $\mathrm{CO}_{2}$ concentration in the ambient air has a greater influence on the internal concentration than would be expected. Outer concentrations vary according to the type of weather, location (country, city...) and the season in values ranging from about $300-500 \mathrm{ppm}$. It then has a significant influence on the resulting internal $\mathrm{CO}_{2}$ concentration.

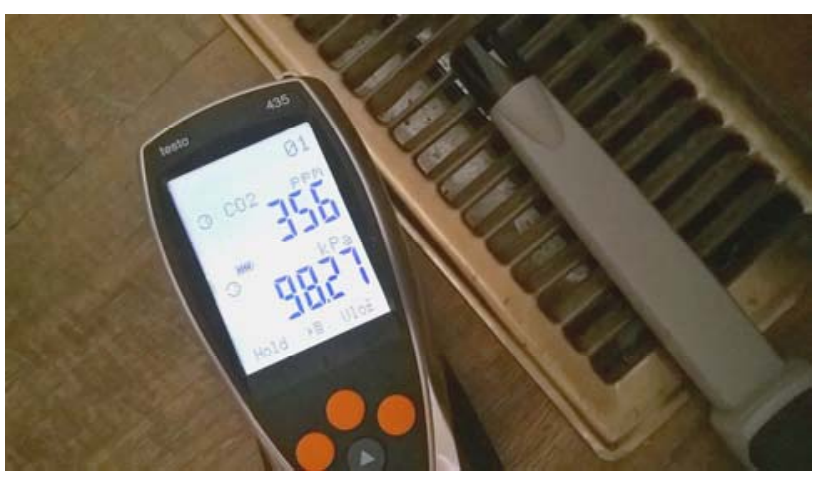

Figure 5. Measurement of external $\mathrm{CO}_{2}$ concentration on outlet (Testo 435-2 and IAQ sensor).

\subsection{Results from the subsidiary sensors}

When measuring the internal $\mathrm{CO}_{2}$ concentrations another subsidiary measurement was performed using eight 
secondary Comet T6450 sensors, which were located (suspended) in opposite corners, $1 \mathrm{~m}$ from the surrounding walls and $0.75 \mathrm{~m}$ above the floor, superimposed on each other hung (4 pieces sensors), see Fig. 1. These curves for other flows and measurements also correspond to the central Siemens Desigo gauge system (Figure 4).

At the next figures (from Comet Database software) is brightly visible the difference among the development of $\mathrm{CO}_{2}$ concentration and the finally values. Measuring steps were every 10 seconds.

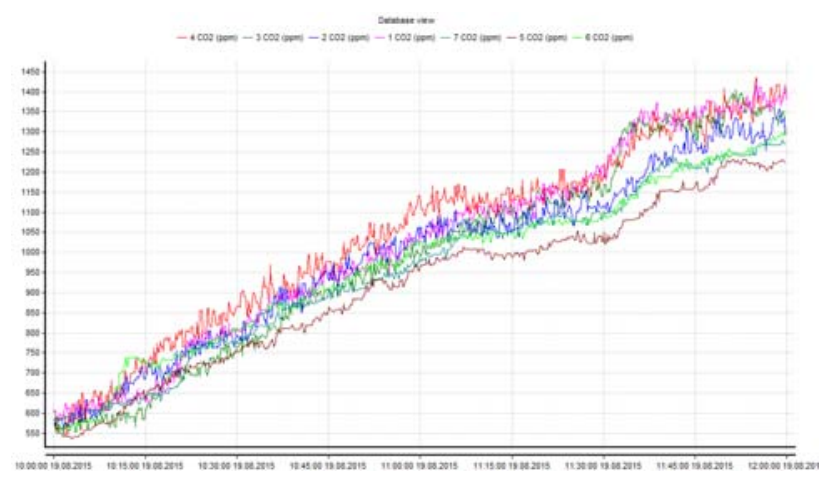

Figure 6. Measurement process of $\mathrm{CO}_{2}$ concentration in tested room with flow of $15 \mathrm{~m}^{3} / \mathrm{h}$ of fresh.

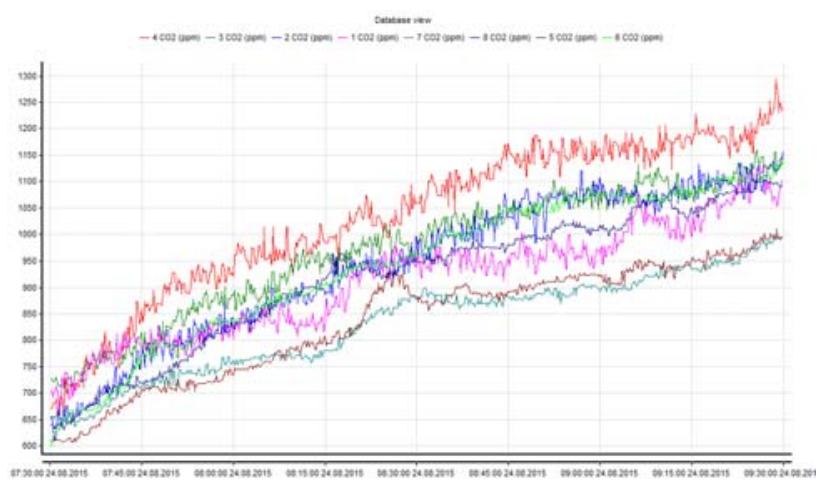

Figure 7. Measurement process of $\mathrm{CO}_{2}$ concentration in tested room with flow of $25 \mathrm{~m}^{3} / \mathrm{h}$ of fresh air.

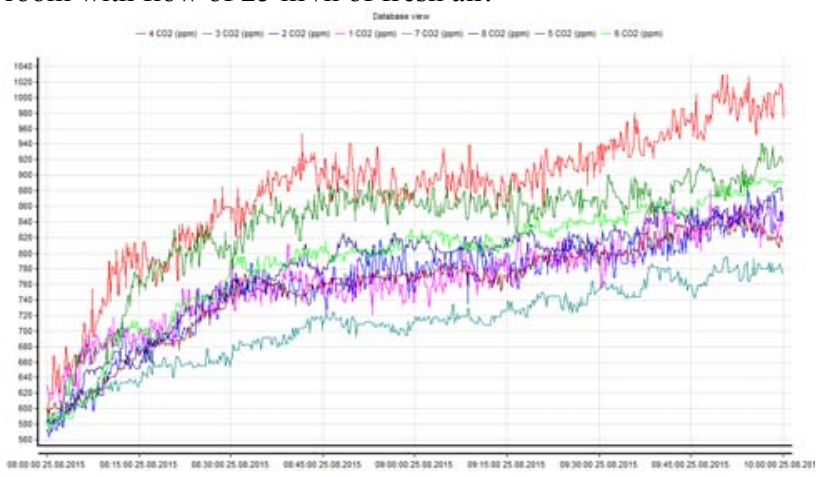

Figure 8. Measurement process of $\mathrm{CO}_{2}$ concentration in tested room with flow of $50 \mathrm{~m}^{3} / \mathrm{h}$ of fresh air, rainy day.

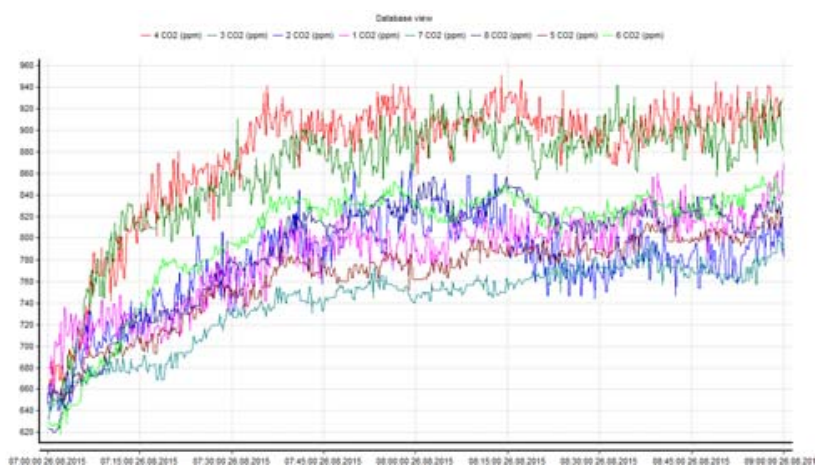

Figure 9. Measurement process of $\mathrm{CO}_{2}$ concentration in tested room with flow of $50 \mathrm{~m}^{3} / \mathrm{h}$ of fresh air.

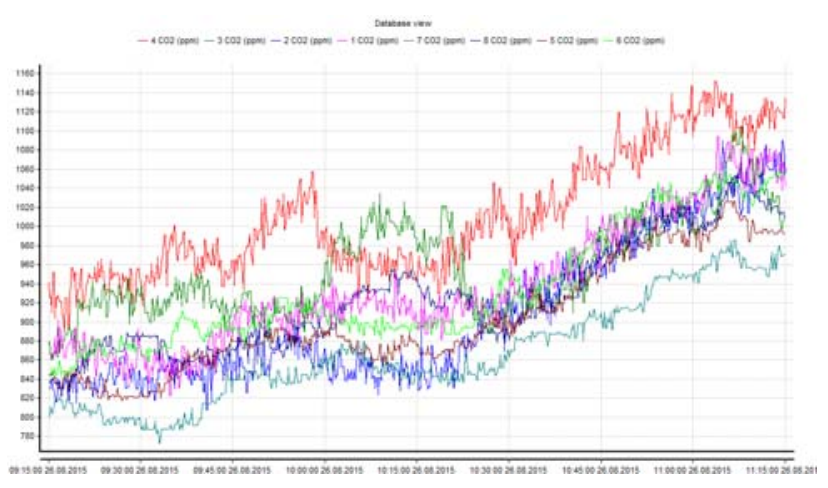

Figure 10. Measurement process of $\mathrm{CO}_{2}$ concentration in tested room with flow of $40 \mathrm{~m}^{3} / \mathrm{h}$ of fresh air.

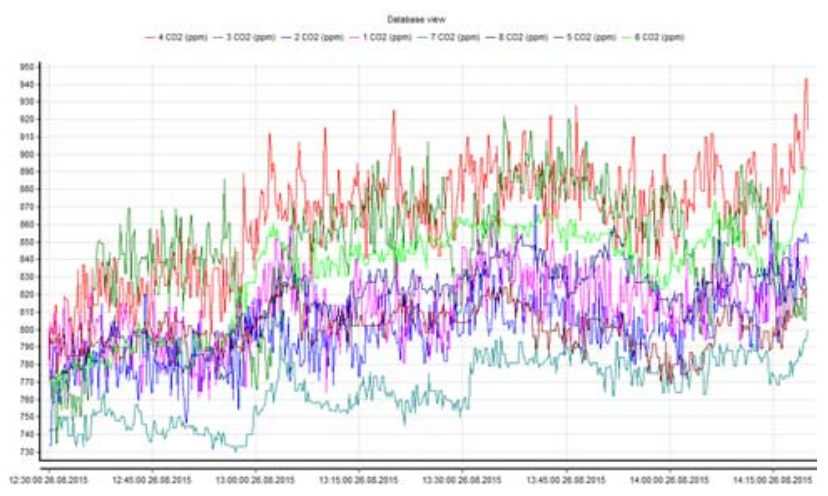

Figure 11. Measurement process of $\mathrm{CO}_{2}$ concentration in tested room with flow of $60 \mathrm{~m}^{3} / \mathrm{h}$ of fresh air.

The chart shows the behavior of concentrations in the area with the individual flow ratings, see Fig. 4. For the higher flow ratings 50 and $60 \mathrm{~m}^{3} / \mathrm{h}$, stabilization of the concentration in the room at around $800 \mathrm{ppm}$ is apparent. Lower flow ratings, mainly 15 and $25 \mathrm{~m}^{3} / \mathrm{h}$ per person, are not able to maintain the required concentration at the recommended limit of 1000 ppm by the Pettenkofer Criteria. 
Table 2. Average $\mathrm{CO}_{2}$ values calculated from the maximum values in tested room with variable flow of fresh air after two hours.

\begin{tabular}{|c|c|c|c|c|c|c|}
\hline Outer CO2 [ppm] & $330-340$ & 370 & $355-440$ & 395 & $370-500$ & $385-430$ \\
\hline Sensor / Fresh air $[\mathrm{m} 3 / \mathbf{h}]$ & 15 & 25 & 50 & 50 & 40 & 60 \\
\hline $\mathrm{CO} 21$ & 1380.0 & 1103.0 & 906.0 & 870.0 & 1058.0 & 860.0 \\
\hline $\mathrm{CO} 22$ & 1295.0 & 1157.0 & 926.0 & 782.0 & 1020.0 & 838.0 \\
\hline $\mathrm{CO} 23$ & 1297.0 & 1147.0 & 977.0 & 882.0 & 1063.0 & 879.0 \\
\hline $\mathrm{CO} 24$ & 1392.0 & 1239.0 & 1012.0 & 929.0 & 1126.0 & 823.0 \\
\hline $\mathrm{CO} 25$ & 1225.0 & 996.0 & 868.0 & 820.0 & 991.0 & 848.0 \\
\hline $\mathrm{CO} 26$ & 1292.0 & 1139.0 & 926.0 & 844.0 & 1040.0 & 884.0 \\
\hline $\mathrm{CO} 27$ & 1271.0 & 993.0 & 908.0 & 795.0 & 980.0 & 819.0 \\
\hline $\mathrm{CO} 28$ & 1249.0 & 1092.0 & 912.0 & 834.0 & 1028.0 & 911.0 \\
\hline Average Values CO2 [ppm] & 1300.1 & 1108.3 & 929.4 & 844.5 & 1038.3 & 857.8 \\
\hline
\end{tabular}

Comparing between two tables 1 and 2 it is apparent that the resulting values are not too different. The differences in the resulting concentrations are caused by sensor deviation.

Without the air exchange, after an hour the concentration of $\mathrm{CO}_{2}$ in the room would be approximately $0.89 \%$, thus $890 \mathrm{ppm}\left(50.2 \mathrm{~m}^{3} \times 0.45-\right.$ $0.50 \mathrm{~m}^{3} / \mathrm{h}$ ). Detailed measurements took place in 2014 [2, 3]. Therefore, it is necessary to continuously ventilate the room. Human exhaled air has a concentration of about 35000 to $50000 \mathrm{ppm}$.

\subsection{Interior temperature and relative humidity}

Outside temperature during the individual measurements varied from $25^{\circ} \mathrm{C}$ to $30^{\circ} \mathrm{C}$. Total solar radiation had an effect on the thermal load inside the tested room and consequently on the initial temperature inside the room. The temperature during the measurement usually increased due to the heat emission of one person - man (sensible heat about $62 \mathrm{~W}$ at $26^{\circ} \mathrm{C}$ ) and one laptop to check the results of the Comet sensors, see Figure 12.

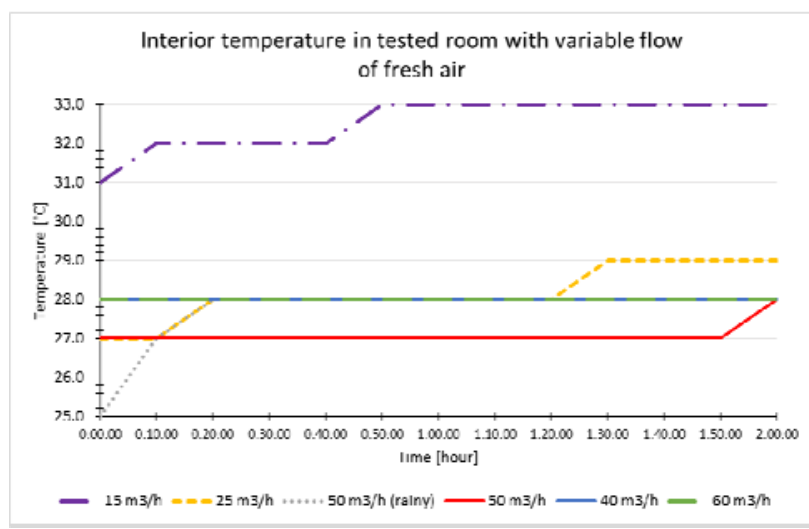

Figure 12. Temperature in tested room with variable flow of fresh air.

Values of $1500 \mathrm{ppm}$ were not achieved (a longer period of time would be necessary), see [3], but at this level a person feels so-called heavy air, more sweating and impending malaise (note the author's own measurements). The feeling between fresh air and highly concentrated $\mathrm{CO}_{2}$ is quite diametrical, especially when leaving the testing room and then coming back.
Only with high levels of air exchange of $60 \mathrm{~m}^{3} / \mathrm{h}$ was it possible to maintain a relatively constant internal temperature and internal relative humidity, see Fig. 13. However, during measurements at $60 \mathrm{~m}^{3} / \mathrm{h}$, the outdoor temperature was $25^{\circ} \mathrm{C}$.

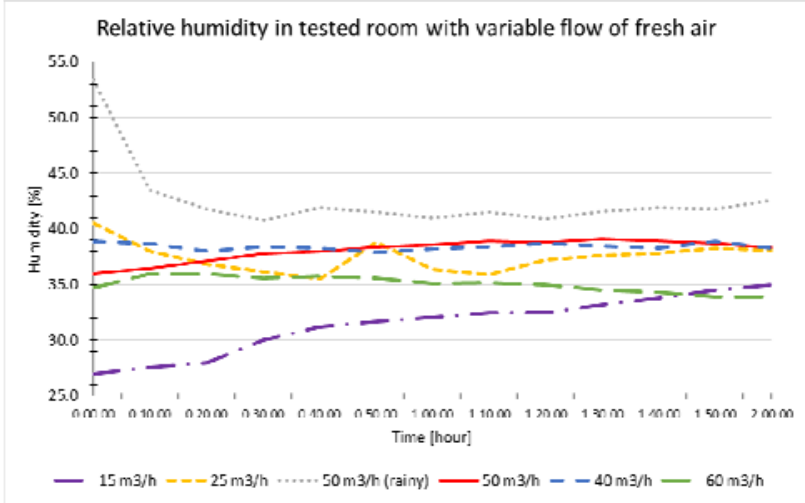

Figure 13. Relative humidity in tested room with variable flow of fresh air.

\section{Conclusion and solution}

A solution to maintaining the level of $\mathrm{CO}_{2}$ concentration in a room is to maintain the flow at about $40 \mathrm{~m}^{3} / \mathrm{h}$ and more. Do not propose ventilation systems with low levels of air flow. This recommendation is valid above all for the period when a person is in the room, during mental activity and rest. During the sleep it is possible reduce this flow to $30 \mathrm{~m}^{3} / \mathrm{h}$. Physical workload requires an even greater supply of fresh air than $50 \mathrm{~m}^{3} / \mathrm{h}$.

If we consider air heating, the demand for energy will be a little higher, but a healthy microclimate will remain. That's more important. From the measurement results it is recommended that the volume of fresh air into the room should not be lower than $50 \mathrm{~m}^{3} / \mathrm{h}$ and to avoid favoring energy consumption over the health aspect.

\section{Acknowledgement}

The work was supported by the conceptual development of science, research and innovation for year 2015 allocated to VSB-TUO by the Ministry of Education, Youth and Sports of the Czech Republic.

\section{References}

[1] Costanzo, S., A. Cusumano a C. Giaconia. Ventilation Rates and Unsatisfied Percentage from Indoor $\mathrm{CO}_{2}$ Concentration. Sage Publications Ltd. 2011, no. 2. DOI: 10.1177/1420326X10373330

[2] Sipkova, V., Galda, Z., Labudek, J., Hibler, D.: Influence of plants on the $\mathrm{CO}_{2}$ concentration in the passive house. In: The 6th International Conference on Contemporary Problems of Architecture and Construction. Ostrava, Czech Republic: VŠB Technical University of Ostrava, 2014, s. 5. ISBN 978-80-248-3147-3.

DOI: 
[3] Galda, Z., Labudek, J., Sipkova, V.: Experimental Measurement of the $\mathrm{CO}_{2}$ Content in a Passive Home During a Simulated Air-Conditioning Power Outage, Applied Mechanics and Materials Vols. $752-753$ (2015) pp 1187-1190, Trans Tech Publications, Switzerland, DOI:10.4028/www.scientific.net/AMM.752753.1187

[4] CSN EN 15665:2011 Ventilation for buildings Determining performance criteria for residential ventilation systems/Větrání budov - Stanovení výkonových kritérií pro větrací systémy obytných budov, CNI, Prague.

[5] Public notice no. 20/2012 Coll., which changes public notice no. 268/2009 Coll., about technical requirements on buildings.

[6] http://www.vyzkumneinovacnicentrum.cz/fotog alerie/\#hrefHeader 